\title{
Antidepressant and skeletal muscle relaxant effects of the aqueous extract of the Prosopis cineraria
}

\author{
Mathew George ${ }^{1, *}$, Lincy Joseph ${ }^{1}$, Abishika Sharma ${ }^{2}$ \\ ${ }^{1}$ Pushpagiri College of Pharmacy, Kerala, India, ${ }^{2}$ School of Pharmaceutical Sciences, SU, India
}

\begin{abstract}
The aqueous leaves extract of Prosopis cineraria (AEPC) is used traditionally for the treatment of various CNS disorder. The purpose of this study was to evaluate the extract for antidepressant and skeletal muscle relaxant activity. The antidepressant effect of the extract was evaluated using Forced swim test (FST). The immobility periods of control and treated mice were recorded. The antidepressant-like effect of tested compound was compared to that of imipramine (15 mg/kg. p.o). Muscle relaxant property was studied using rotarod apparatus and total fall off time for standard and control group was recorded. Phytochemical screening revealed the presence of saponins, flavonoids, alkaloids, glycosides, tannins and phenolic compounds. The leaf extract at doses of $200 \mathrm{mg} / \mathrm{kg}$ significantly decreased the duration of immobility time in FST. The efficacy of tested extract was found to be comparable to that of imipramine. Our results suggested that the aqueous extract of Prosopis cineraria leaves exerts antidepressant-like effect.
\end{abstract}

Uniterms: Proposis cineraria/pharmacognosy. Proposis cineraria/extract/antidepressant effect. Proposis cineraria/extract/relaxant property. Skeletal muscle. Imipramine/comparative study. Diazepam/ comparative study.

\begin{abstract}
O extrato aquoso de folhas de Prosopis cineraria (AEPC) é utilizado, tradicionalmente, para o tratamento de várias disfunções do SNC. O propósito desse estudo foi avaliar o extrato quanto às atividades antidepressiva e relaxante muscular esquelética. $\mathrm{O}$ efeito antidepressivo do extrato foi avaliado usando o teste do nado forçado (FST). Registraram-se os períodos de imobilidade dos camundongos controle e dos tratados. O efeito antidepressivo do composto testado foi comparado com a imipramina ((15 mg/ kg. p.o). A propriedade relaxante muscular foi estudada usando o cilindro giratório e o tempo total de queda para os grupos padrão e controle foram registrados. A triagem fitoquímica revelou a presença de saponinas, flavonoides, alcaloides, glicosídeos, taninos e compostos fenólicos. O extrato da folha em doses de $200 \mathrm{mg} / \mathrm{kg}$ diminui significativamente a duração do tempo de imobilidade no FST. A eficácia do extrato testado foi comparável àquela da imipramina. Nossos resultados sugeriram que o extrato aquoso das folhas da Prosopis cineraria exerce efeito semelhante ao antidepressivo.
\end{abstract}

Unitermos: Proposis cineraria/farmacognosia. Proposis cineraria/extrato/efeito antidepressivo. Proposis cineraria/extrato/propriedade relaxante. Músculo esquelético. Imipramina/estudo comparativo. Diazepam/estudo comparativo.

\section{INTRODUCTION}

According to the World Health Organization report (WHO, Geneva; 2001) approximately 450 million people suffer from a mental or behavioral disorder. This amounts to $12.3 \%$ of the global burden of disease, and will rise to $15 \%$ by 2020 (Reynolds, Brain, Mind, 2003). Psychiatric

\footnotetext{
*Correspondence: M. George. Pushpagiri College of Pharmacy, Kerala, India. E-mail: mathewlincg@yahoo.com
}

illness is also often associated with suicide and there are between 10 and 20 million suicide attempts every year. Depression is the most prevalent mental disorder and depression is recognized to be symptomatically, psychologically and biologically heterogeneous (Thase, Howland, 1995). The disorder was characterized by apathy, loss of energy, retardation of thinking and activity, as well as profound feelings of gloominess, despair and suicidal ideation. In spite of the availability of antidepressant drugs like tricyclic antidepressants, selective reversible inhibitors 
of monoamine oxidase-A (MAO-A), selective serotonin reuptake inhibitors (SSRIs) and selective noradrenaline reuptake inhibitors (SNRIs), depression continue to be a major medical problem (Yu, Kong, Chen, 2002). Basic neuroscience offers the promise of improving our understanding of disease pathophysiology, identifying novel mechanisms that can be targeted by more effective pharmacotherapies and screening of herbal sources of drugs. These considerations implicate the search for new antidepressant agents that have a fast onset of action. Various plants are being used in complementary and alternative medicines for management of mood disorders. On the basis of the above information, the leaves of Prosopis cineraria was selected for evaluating its antidepressant and muscle relaxant activity due to its traditional use in the management of various CNS disorders.

Prosopis cineraria (Fabaceae), locally known as 'Khejri', has a long history of use in herbal medicine in arid and semi-arid regions in greater parts of India, Burma and Sri Lanka. Since all parts of the tree are useful, it is called 'Kalptaru' (Burkart, 1976). Ancient literature has reported the use of $P$. cineraria as folk medicine for various ailments like fever and pain. Its flowers mixed with sugar when administered orally prevent miscarriage (N.A.S., 1980). Dry pods of the plant help in preventing protein calorie malnutrition and iron calcium deficiency in blood. Smoke of leaves is used to cure eye infections (Chandrashekhar, 2010, Dehradun, 1993). Bark of the tree is used in the treatment of asthma, bronchitis, dysentery, leucoderma, leprosy (Shalini, 1997), muscle tremors and piles (Toky, 1999). Numerous bioactive compounds such as flavonoids, alkaloids, diketones, phenolic contents, free amino acids, patulitrin, spicigerin, prosogerin $\mathrm{A}, \mathrm{B}, \mathrm{C}, \mathrm{D}$, lipids, $\beta$-sitosterol, sugars and vitamins have been isolated from various parts of the plant. Some of these bioactive compounds have been worked out for one or the other medicinal attributes (Purohit, Ramawat, Arya, 1979; Rhoades, 1979). But till date, the antidepressant and muscle relaxant potential of $P$. cineraria has not been scientifically evaluated. Hence, in the present study, the effect of oral treatment with $P$. cineraria leaves extract at a dose of $200 \mathrm{mg} / \mathrm{kg}$ body wt on antidepressant and skeletal muscle relaxant activity has been studied.

\section{MATERIAL AND METHODS}

\section{Preparation of extract}

Leaves of $P$. cineraria was collected from the plants available locally (Dist. Tonk, Rajasthan, India). It was taxonomically identified. Dried leaves were subjected to size reduction to a coarse powder which was then ex- tracted in soxhlet apparatus with water and concentrated to dryness under reduced pressure at $60 \pm 1^{\circ} \mathrm{C}$ in a vacuum rotatory evaporator. The extract was dried at $40-45^{\circ} \mathrm{C}$ in hot air oven till solid to semisolid mass was obtained. The yield of extract was $4.2 \% \mathrm{w} / \mathrm{w}$ (with respect to crude material). The suspension of extract of the leaves, prepared in distilled water was used in the experiment.

\section{Phytochemical screening}

The aqueous extract of Prosopis cineraria was screened for various chemical constituents (simple sugars, tannins, alkaloids, cardiac glycosides, flavonoids, steroidal compounds, saponins, anthracene derivatives and simple sugars) using established methods (Purohit, Ramawat, Arya, 1979; Rhoades, 1979).

\section{Animals}

Swiss albino mice (6-8 weeks) of either sex weighing 25-30 g were used. They were housed in light controlled room $(12: 12 \mathrm{~h})$ and at constant temperature $\left(22+2^{\circ} \mathrm{C}\right)$ conditions. Animals were fed with standard laboratory diet and water.

\section{Toxicity studies}

The acute toxicity study was done according to OECD guidelines, 407 (OECD, 1995). The compounds were administered orally in different doses, where $24 \mathrm{~h}$ toxicity was recorded to identify the toxic does. The dose of the test compounds was then fixed on the basis of their acute toxicity as $200 \mathrm{mg} / \mathrm{kg}$ for evaluation.

\section{Forced swim test (FST)}

Forced swim test, the most frequently used behavioral model for screening antidepressant-like activity in rodents, was first proposed by Porsolt (Porsolt, Bertin, Jalfre, 1977). The procedure was same as followed previously. Mice were individually forced to swim in open glass chamber $(25 \times$ $15 \times 25 \mathrm{~cm}$ ) containing fresh water to a height of $15 \mathrm{~cm}$ and maintained at $26 \pm 1{ }^{\circ} \mathrm{C}$ (Dunham, Miya; 1957). At this height of water, animals were not able to support themselves by touching the bottom or the side walls of the chamber with their hind-paws or tail. Water in the chamber was changed after subjecting each animal to FST because "used water" has been shown to alter the behavior. Each animal showed vigorous movement during initial $2 \mathrm{~min}$ period of the test. The duration of immobility was manually recorded during the next 4 min of the total 6 min testing period. 
TABLE I - Effect of $P$. cineraria on duration of immobility in forced swim test

\begin{tabular}{lcccc}
\hline S.no & Treatment & Dose $(\mathrm{mg} / \mathrm{kg})$ & $\begin{array}{c}\text { Immobility time } \\
(\text { Mean } \pm \text { S.E.M) }\end{array}$ & \% decrease \\
\hline 1. & Control & ----- & $154.15 \pm 3.64$ & ------ \\
2. & Imipramine & 15 & $35.7 \pm 1.347^{* *}$ & 76.84 \\
3. & AEPC & 200 & $46.3 \pm 1.96^{* *}$ & 69.96 \\
\hline
\end{tabular}

Each value is the Mean \pm S.E.M. for 5 mice, ${ }^{* *}$ - $\mathrm{P}<0.01$

TABLE II - Effect of $P$ cineraria on fall off Time in rotarod test

\begin{tabular}{lcccc}
\hline \multirow{2}{*}{ Groups } & \multicolumn{4}{c}{ FALL OFF TIME (in seconds) } \\
\cline { 2 - 5 } & Initial & After 30 min. & After 60 min. & After 120 min. \\
\hline Control & $283.37 \pm 1.04$ & $239.15 \pm 0.997$ & $229.43 \pm 1.780$ & $213.45 \pm 2.509$ \\
Diazepam & $260.12 \pm 2.28$ & $18.04 \pm 1.45^{* *}$ & $17.23 \pm 0.748^{* *}$ & $18.06 \pm 0.652^{* *}$ \\
AEPC & $268.62 \pm 2.09$ & $20.96 \pm 1.863^{* *}$ & $22.12 \pm 2.68^{* *}$ & $29.36 \pm 2.707^{*}$ \\
\hline
\end{tabular}

Values expressed in Mean $\pm \operatorname{SEM}(\mathrm{n}=5) .{ }^{*} \mathrm{p}<0.05 ;{ }^{*}{ }_{-} \mathrm{P}<0.01$ when compared with control group

Mice were considered to be immobile when they ceased struggling and remained floating motionless in water, making only those movements necessary to keep their head above water. Following swimming session, mice were towel dried and returned to their housing conditions (Dhingra, Sharma, 2006).

\section{Skeletal muscle relaxant activity}

Mice were divided into three groups consisting of five animals each. Group I served as control which received distilled water. Animals of group II received standard drug Diazepam at a dose of $(1 \mathrm{mg} / \mathrm{kg}$, i.p. $)$. Group III received the $A E P C$ orally at a dose of $200 \mathrm{mg} /$ $\mathrm{kg}$. Animals remaining on Rota-Rod (20-25 rpm) $2 \mathrm{~min}$ or more in low successive trials were selected for testing. The test compounds can administer intraperitoneally or orally. Thirty minutes after intraperitoneal or $60 \mathrm{~min}$ after oral administration the mice were placed on the rotating rod. The fall off time from the rotating rod was noted after 30,60 and 120 minutes after drug administration. The difference in the fall off time from the rotating rod between the control and the treated mice was taken as an index of muscle relaxation (Perez et al; 1998) (Nagger et al, 2003).

\section{Statistical analysis}

Statistical significance was analysed using one-way ANOVA followed by Bonferroni test and $\mathrm{P}<0.05$ was considered significant.

\section{RESULTS}

The preliminary phytochemical screening of the dry residue showed the presence of saponins, flavonoids, alkaloids, glycosides, tannins and phenolic compounds. In acute toxicity study, the aqueous extract of $P$. cineraria was found to be safe and no mortality was observed at a dose as high as $2 \mathrm{~g} / \mathrm{kg}$. The effects of extract on duration of immobility in FST in mice have been shown in Table I; Figure 1. P. cineraria at dose $200 \mathrm{mg} / \mathrm{kg}$ b.w produced a significant $(\mathrm{P}<0.05)$ decrease in duration of immobility $(46.3 \pm 1.96)$ in comparison with the control group (154.15 \pm 3.64$)$. Similarly animals treated with imipramine $(15 \mathrm{mg} / \mathrm{kg})$ shows a significant decrease in immobility time (35.7 \pm 1.347$)$.

The effect of extract on muscle relaxant action have been shown in Table II; Figure 2. P cineraria at dose

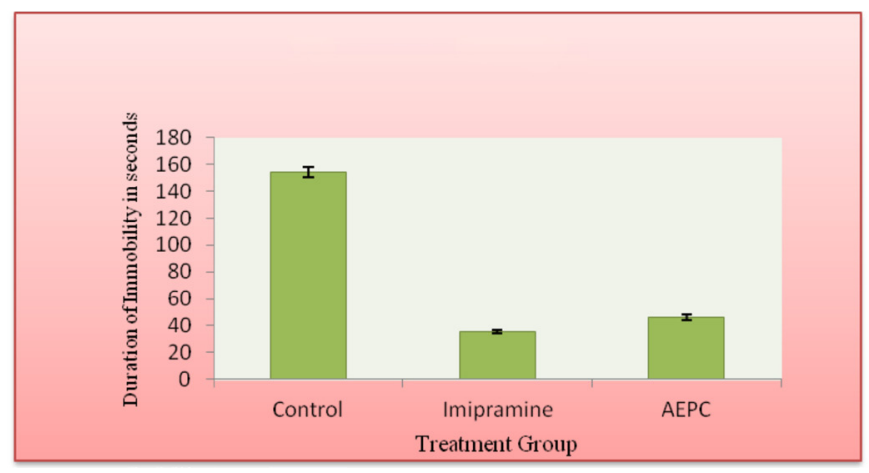

FIGURE 1 - Effect of $P$. cineraria on duration of immobility in forced swim test. 


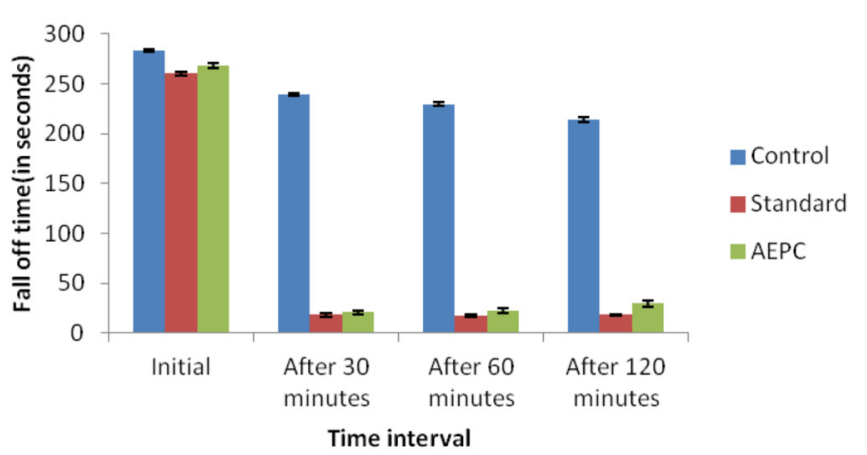

FIGURE 2 - Effect of $P$ cineraria on fall off Time in rotarod test.

$200 \mathrm{mg} / \mathrm{kg}$ b.w produced a significant $(\mathrm{P}<0.05)$ decrease in Fall off time $(20.96 \pm 1.863,22.12 \pm 2.68,29.36 \pm 2.707)$ in comparison with control $(239.15 \pm 0.997,229.43 \pm 1.780$, $213.45 \pm 2.509$ ) after 30,60 and 120 minutes of oral administration respectively. Similarly animals treated with Diazepam $(1 \mathrm{mg} / \mathrm{kg})$ shows a significant decrease in immobility time $(18.04 \pm 1.45,17.23 \pm 0.748,18.06 \pm 0.652)$.

\section{DISCUSSION AND CONCLUSION}

In the present work attempts were made to study detail phytochemical investigation and pharmacological action, particularly anti-pyretic and analgesic activity of leaf of $P$. cineraria. The phytochemical analysis of the dry residue showed the presence of saponins, flavonoids, alkaloids, glycosides, tannins and phenolic compounds.

The two most widely used animal models for antidepressant screening are the forced swimming and tail suspension tests. The Forced Swim is quite sensitive and relatively specific to all major classes of antidepressants (Porsolt, Bertin, Jalfre, 1977). In the FST, mice are forced to swim in restricted space from which they cannot escape. This induces a state of behavioral despair in animals, which is claimed to reproduce a condition similar to human depression (Willner; 1984).

Results showed that the administration of the AEPC produced a diminution of immobility time of mice exposed to the forced swimming test. In the study, aqueous extract $(200 \mathrm{mg} / \mathrm{kg})$ administered to mice, produced significant antidepressant-like effect in FST and its efficacy was found to be comparable to imipramine $(15 \mathrm{mg} / \mathrm{kg})$.

For Skeletal muscle relaxant action rotarod test is used. The test is used to evaluate the activity of drugs interfering with motor coordination. In 1956, Dunham and Miya suggested that the skeletal muscle relaxation induced by a test compound could be evaluated by testing the ability of mice or rats to remain on a revolving rod. This forced motor activity has subsequently been used by many investigators. The dose which impairs the ability of $50 \%$ of the mice to remain on the revolving rod is considered the endpoint. By this test the muscle relaxant potency in a series of compounds such as the benzodiazepines (Vogel et al) have been performed.

Results showed that the administration of the AEPC produced a significant decrease in fall off time and its efficacy was found to be comparable with Diazepam $(1 \mathrm{mg} / \mathrm{kg})$.

Based on the results of the present study, we conclude that the aqueous extract of $P$. cineraria possess significant antidepressant like effect and skeletal muscle relaxant activity. The activity may be due to the alkaloids, tannins and flavonoid which are present in the leaves extract. However, further studies are necessary to find the exact mechanism of antidepresant and skeletal muscle relaxant effect and to isolate the active compound(s) responsible for this pharmacological activity.

\section{REFERENCES}

BURKART, A. A monograph of genus Prosopis (Leguminous). J. Arnold Arboretum, v.57, p.450-525, 1976.

CHANDRASHEKHAR, C.H.; LATHA K.P.; VAGDEVI, H.M.; VAIDYA, V.P. In vitro anthelmintic efficacy of the Prosopis staphaniana extracts. Der Pharma Chemica, v.2, p.405-409, 2010.

DHINGRA, D.; SHARMA, A. Antidepressant-like activity of Glycyrrhiza glabra. Prog. Neuropsychopharmacol. Biol. Psych., v.30, p.449-454, 2006.

DUNHAM, N.M.; MIYA, T.S. A note on simple apparatus for detecting neurological deficit in rats and mice. J. Am. Pharm., v.46, p.208-209, 1957.

NAGGAR, T.B.A.L.; GÓMEZ-SERRANILLOS, M.P.; CARRETERO, M.E.; VILLAR, A.M. Seed Extract modulates the neurotransmitter amino acids release in cultured neurons in vitro. J. Ethnopharmacol., v.88, p.63$68,2003$.

NATIONAL ACADEMY OF SCIENCES. N.A.S. Firewood crops shrub and tree species for energy production. Washington DC: National Academy Press, 1980. v.1, p.235.

ORGANIZATION FOR ECONOMIC CO-OPERATION AND DEVELOPMENT. OECD. Guidelines for testing of chemicals. section 4: Health Effects. Available at: $<$ http:// oecd.org/chemicalsafety/assessmentofchemicals/1948386. pdf $>$. Acessed on: 10 Sep. 2012. 
PEREZ, G.R.M.; PEREZ, L.J.A.; GARCIA, D.L.M.; SOSSA, M.H. Neuropharmacological activity of Solanum nigrum fruit. J. Ethnopharmacol., v.62, p.43-48, 1998.

PORSOLT, R.D.; BERTIN, A.; JALFRE, M. Behavioral despair in mice: A primary screening test for antidepressants. Arch. Int. Pharmacodyn. Ther., v.229, p.327-336, 1977.

PUROHIT, S.D.; RAMAWAT, K.G.; ARYA, H.C. Phenolics, peroxidase and phenolase as related to gall formation in some arid zone plants. Curr. Sci., v.48, p.714-716, 1979.

REYNOLDS, E.H. Brain and mind: a challenge for WHO. Lancet, v.361, p.1924-1925, 2003.

RHOADES, D.F. Herbivores, evolution of plant chemical defense against herbivores: their interaction with secondary plant metabolites. New York: Academic Press; p.3-54,1979.
SHALINI, K. Vedic leguminous plants: medicinal and microbiological study. New Delhi: Calssical Publishing Company, 1997. 96 p.

THASE, M.E.; HOWLAND, R.H. Biological processes in depression: an update and integration. In: BECKHAM, E.E.; LEBER, W.R. (Eds.). Handbook of depression. 2.ed. New York: Guilford, 1995. p.213-279.

TOKY, O.P . Medicinal values of Prosopis cineraria in arid and semi arid India. Bulletin of Society of chemical industry, Vol.1, p.1-10,1999.

WORLD HEALTH ORGANIZATION. WHO. Mental health: new understanding new hope. Geneva, 2001. chap.2, p.29. (Report).

Received for publication on $23^{\text {th }}$ August 2011 Accepted for publication on $05^{\text {th }}$ April 2012 
